\title{
An Effect Of Management Service Quality On Residential Satisfaction And Recommended Intention Of High-Rise Apartments
}

\author{
Feng Jing ${ }^{1}$, Chae-Kwan Lim²* \\ ${ }^{1}$ Graduate Student, Doctor's degree, Department of Business Administration, Tongmyong University, South \\ Korea \\ ${ }^{2 *}$ Professor, Corresponding Author, Department of Distribution Management, Tongmyong University, South \\ Korea
}

Article History: Received:11 January 2021; Accepted: 27 February 2021; Published online: 5 April 2021

\begin{abstract}
Recently, a lot of high-rise apartments are being built around large cities in the world. The highrise apartments are a valuable living space for residents and are located in the center of the city, providing a distinctive and advanced residents' convenience while maintaining a high price of real estate along with the landmark role. In this background this study examined the relationship between the evaluation of the quality of management services perceived by residents and the satisfaction and recommendation intention of tenants living in high-rise apartments in China. This study empirically examines the relationship between the quality of management services (environmental quality, process quality, result quality), satisfaction and recommendation intention of tenants living in 'high-rise apartments' in large cities in China. The results showed that the quality of management services of high-rise apartments had a significant effect on residential satisfaction and recommended intention. In addition, among the quality of management service affecting residential satisfaction and recommendation intention, the relationship was the highest in the order of process quality $(\beta=.363, t=5.362)$, result quality $(\beta=.306, \mathrm{t}=5.610)$, and environmental quality $(\beta=.200, \mathrm{t}=3.319)$. Therefore, in order to enhance the satisfaction of the residents of high-rise apartments and to induce positive attitudes and follow-up actions, it is necessary to pay attention to the needs of the residents and deal with them promptly and kindly, rather than the physical environmental quality of the high-rise apartments and the quality improvement efforts shown in the research results. Therefore, in order to enhance the satisfaction of the residents of high-rise apartments and to induce positive attitudes and follow-up actions, it is necessary to pay attention to the needs of the residents and deal with them promptly and kindly, rather than the physical environmental quality of the high-rise apartments and the quality improvement efforts shown in the research results. It can be said to be an important implication confirmed through this study.
\end{abstract}

Keywords - high-rise apartments, environment quality, process quality, result quality, residential satisfaction, recommended intention

\section{INTRODUCTION}

In the 1990s, the use of high-rise buildings in China was mainly used for business and commercial functions, but recently it has been developed for complex uses such as hotels and apartments due to economic and functional considerations. High-rise residential complex apartments that have recently been built in the metropolitan area within China are precious residential spaces for residents, not only offering differentiated and advanced convenience but also maintaining somewhat higher price of properties.

Especially as the entire society is being converted into service-centered economy and its subsequent competition mounts, even in the case of building maintenance, demand for some advanced service has increased. Accordingly, the necessity for policies in the field of building maintenance emerged that improve the quality of property maintenance service and increase customers' satisfaction on all kinds of management services. Despite of such practical necessity, however, the empirical study as to the management service of high-rise residential complex apartment is not very active.

In this perspective, although a systemic, scientific study is necessary in terms of microcosmic dimensions on management service of high-rise residential complex apartment, the existing precedents related are extremely limited in that they focused on functional and technological characteristics, related law, and location such as floor plan, not on residents' practical satisfaction on the structure. Besides, it is true that some research on residential satisfaction lacks approaches to the concepts such as service quality.

\footnotetext{
Received:

Reviewed:

Accepted:

* Corresponding Author
} 
Hence this study has the purpose of making an academic basis of providing more comfortable and convenient residential environment through consumer-centered housing supply in high-rise residential complex apartments by evaluating the quality of management service of residents in high-rise residential complex apartment in China and investigating residents' satisfaction and recommendation intention in the apartment.

This study investigates the characteristics of consumer choice behavior by surveying residents of high-rise residential complex in the Chinese metropolitan area and examines their attitudes, experiences and cognitive behaviors about the management service of high-rise residential complex, with which this study examines residents' satisfaction and recommendation intention on the complex through the aspects of residential use.

This study ushers in the examination of various literature not only domestically but globally and extends its focus on the pursuit of theoretical bases on characteristics of service, degree of satisfaction and recommendation intent by looking up the existing materials. Moreover, it comprises the three elements on the quality of the management service: environment quality, process quality and result quality. Additionally, it analyzes the influence and relationship between the variables in terms of the correlation of variables leading to recommendation intention.

\section{THEORETICAL BACKGROUND}

\subsection{HIGH-RISE BUILDING}

The history of high-rise building beginning from the late 19th century spans around 100 years to the end of the 20th century. On account that the term 'high-rise' implies a little relative concept, it cannot be reduced to a uniform definition [1]. In other words, buildings regarded as high or high-rise ones may be considered ordinary. Furthermore, a single definition of the height of the kind can be relative, making the buildings seen differently according to states, cities, and scholars studying in the area.

Today, the commonly used standard to indicate whether a building is high-rise or not is based on the definitions of CTBUH-Council on Tal Buildings and Urban Habitat. According to the standard, high-rise building is defined as a building having a height of $20 \mathrm{~m}$ or more or 50 stories or more, or a ratio of the bottom and height of 1:5 or more, and one determined by existence of lateral load resistance system. High-rise architecture in the modern sense is considered as a type which has been needed based on the logic of economy or capital, and can be analyzed as a type that develops with the modern technology such as elevator and structural engineering improved. The standards for high-rise buildings can be set up by relative standards in accordance with the era, region, culture, and social differences rather than simply their absolute height [2].

Table 1. Standards for High-Rise Buildings by Country [3]

\begin{tabular}{|c|c|c|c|c|}
\hline Distinc & China & Korea & Japan & United States \\
\hline Basi & $\begin{array}{c}\text { Chinese Civil } \\
\text { Architecture } \\
\text { Design Rule Gl } \\
\text { 50352-205 sec. }\end{array}$ & $\begin{array}{r}\text { Enforcement Ordina } \\
\text { Building Law } \\
\text { Article2 sec. } 1 \text {-1 }\end{array}$ & $\begin{array}{c}\text { Building Standards } \\
\text { Enforcement Ordin } \\
\text { Chapter III Struct } \\
\text { Strength Sec. } 1 \text { Ar } \\
36(3), \\
\text { Article } 20-2 \text { of the }\end{array}$ & $\begin{array}{c}\text { CTBUH definiti } \\
\text { or individual standa } \\
\text { states }\end{array}$ \\
\hline Definit & $\begin{array}{r}\text { the building having } \\
\text { more than } 100 \mathrm{n}\end{array}$ & $\begin{array}{c}\text { the building in whic } \\
\text { number of stories is } \\
\text { more or height is } 20 \\
\text { more }\end{array}$ & $\begin{array}{c}\text { the building over } 60 \\
\text { high }\end{array}$ & $\begin{array}{l}\text { 1)the building over } 5 \\
\text { stories or over } 20 \mathrm{n} \\
\text { high } \\
\text { 2) underside-heighted } \\
\text { 1:5 or greater } \\
\text { 3)the existence of lat } \\
\text { load resistance syst }\end{array}$ \\
\hline
\end{tabular}

\subsection{THE STATUS OF HIGH-RISE BUILDINGS IN CHINA}

Thanks to the rapid growth of urbanized population, China has been building world-class buildings more than any other country on the planet. As of 2018, China has 3,867 high-rise buildings that meet the definition of Chinese Building Act. There are 2,575 buildings over 100m in height, 1,862 buildings over 150m, 678 buildings 
over 200m, and 68 buildings over 300m. Among these, buildings over $150 \mathrm{~m}$ account for much more than any other country in the world.

Table 2. Current Status of Tall Buildings in China (Based on 2018)

\begin{tabular}{|r|rr|r|r|r|}
\hline Distincti & $\begin{array}{r}\text { Total number of hi } \\
\text { building }\end{array}$ & Over 100 & Over 150 & Over 200 & Over 300I \\
\hline \hline China & 5,183 & 2,575 & 1,862 & 678 & 68 \\
\hline United St: & 3,678 & 2,681 & 778 & 198 & 21 \\
\hline
\end{tabular}

In 2018, China built 88 high-rise buildings with more than 200 meters high, making itself become the first in the world, followed by the United States which built 13 buildings. However, the number of high-rise buildings over 100m built by China in 2018 is overwhelmingly over six times more than the US. That accounts for $61.5 \%$ of the world's high-rise buildings built in 2018. In addition, China has renewed the record of building tall buildings annually. 88 constructions were made in 2018, surpassing 86 constructions in 2016, and in 2017, 80 high-rise buildings over $200 \mathrm{~m}$ were built.

The construction of high-rise building has been in a downturn since the global financial crisis in 2008 . However, it has begun to increase rapidly in Asia, mainly China, roughly four or five years ago. The number of high-rise buildings over 200m built annually worldwide increased to 73 in 2013, 104 in 2014, 115 in 2015, and 130 in 2016, and the highest ever in 2017 to 147. In 2018, it slowed somewhat to 143, but the number of the building built in a year was recorded as the second-highest in history since 2017.

Due to the boom of construction in China, the number of skyscrapers worldwide has nearly tripled over the past decade with more than 1,000 new skyscrapers added since the global financial crisis in 2008. The reason why China builds a large number of high-rise buildings is that China's economic growth is first cited, followed by the increase in GDP, expansion of domestic market, and population inflow into cities. And the combination of performanceism and institutional factors inside China can be another reason for the increase of high-rise buildings.

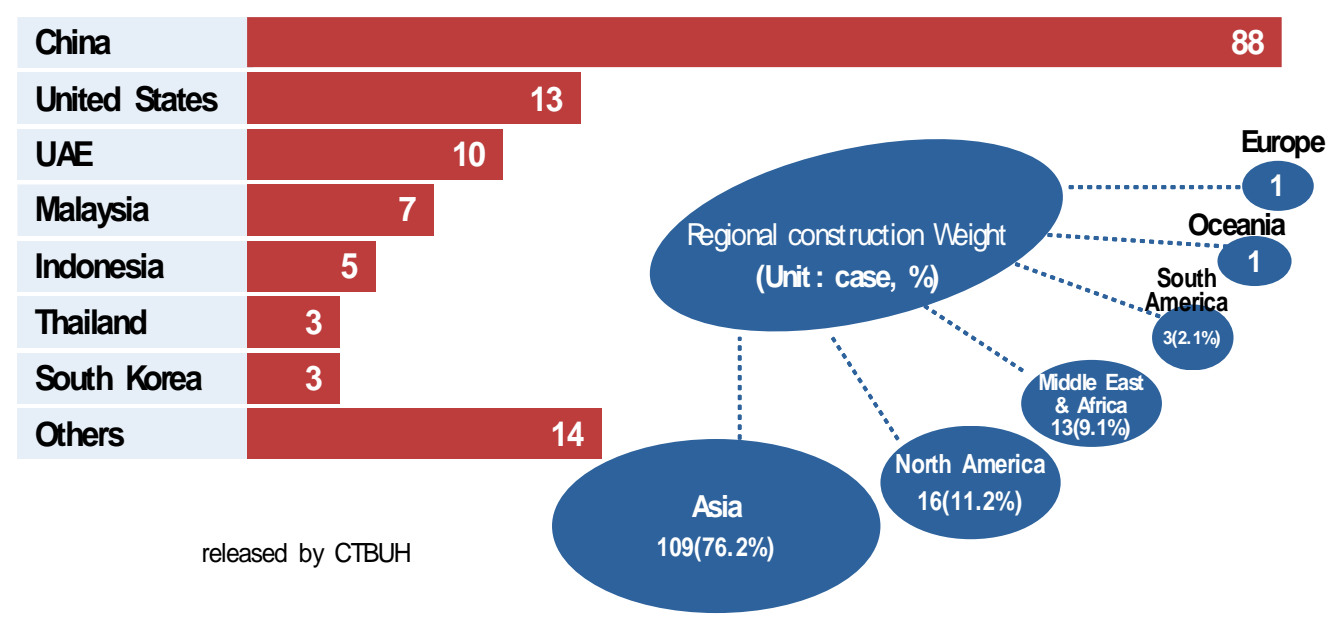

Fig. 1 Newly Built (200M or taller) Global Tall Buildings in 2018 [4]

\subsection{QUALITY OF MANAGEMENT SERVICE}

The quality of service has intangible ambiguities different from the tangible objects such as product. However, in association with the characteristics of the service, the service quality does not deviate from the basic direction of modern quality control-the consistency between the quality of service and customer satisfaction. Therefore, the quality of service is generally defined not as a concept of objective quality but that of subjective quality, and can be defined by the meaning of 'perceived service quality' by consumers [5]. 
This means that the quality of service offered should be consistent with customer's expectation while service quality is defined as a measure of how well the service level provided matches the customer's expectation [6], [7]. Many scholars support the conceptual definition of Parasuraman et al. (1985) which read 'the quality of service is the overall judgment or attitude of an individual in relation to the excellence of a specific service' [8].

It is also shown in Bitner and Hubert's study (1994), which defines service quality as "the overall impression consumers have in relation to the excellence or inferiority of service." Such service quality varies in its diverse theoretical views of the range of services subject to quality assessment [9].

In this study, the quality of management service is a customer-oriented concept that measures customer perception which is defined as the attribute of management service and the satisfaction level of customers who encountered a series of service processes. On the basis of such definition, the study composes the sub-factors of management service quality with environmental quality, process quality, and result quality and analyzes their influence relationship with resident satisfaction.

\subsection{RESIDENTIAL SATISFACTION}

Today, the most noted marketing concept in various fields is customer satisfaction. It is believed that customers who are satisfied with organizations' product and service will bring more profits to the companies. As customer satisfaction became the slogan of companies in the 1980s, companies were absorbed into finding ways to satisfy customers as well as offering services above customers' expectation. Because most managers assume that customer satisfaction and purchasing behavior have much correlation, they believe that the higher customer satisfaction not only can make the higher the consumer's purchase proportion and recommendation rate for the brand or company but also lead to the intention of paying more for products [10].

The concept of customer satisfaction is a key element of marketing concept, and many studies have been conducted to present remarkable research results, but there are some differences depending on the approach and perspective of scholars. Oliver (1981) also described customer satisfaction as the comprehensive psychological state created by customer's mismatched expectation combined with the emotion that consumer had by consumer's earlier experience of purchase [11]. Engel et al., (1982) identified the customer satisfaction as an evaluation [12] of whether the selected product or service matched the beliefs held in advance by customers, and Anderson and Weitz (1992) defined it as the process of matching or discrepancy between expectation and perceived product performance [13].

Ha, Kyu Soo and Jin, Seon Jin (2010) insisted that residential satisfaction refers to the degree of tenant's subjective satisfaction with the house in which they live. They said that the degree of residents' satisfaction was of course related to expectation for a residence of a resident's house, desire, passion, and evaluation for it [14], [15].

On the other hand, at least two requirements must be met to increase customer satisfaction. First, it starts with providing quality products and services that can meet customer expectations from the beginning. It is necessary to supply products faster and provide better services at a lower price even though they are of good quality. Second, effectively and thoroughly dealing with customer complaints is required. In the end, customer satisfaction management is a management method that continuously meets these above two requirements and secures a competitive advantage that cannot be imitated by other companies.

\subsection{RECOMMENDED INTENTION}

Recommendation, when viewed from the perspective of consumer response, is closely related to the behavior after purchase as well as to the customer's information acquisition and his or her purchase. Because word of mouth can affect the purchase and use experience by delivering customer satisfaction or dissatisfaction to others after purchase, the message from customers has a considerable influence [16].

The intention of recommendation has been studied as a 'verbal phenomenon,' and unlike the entire evaluation of experience called 'satisfaction,' word of mouth is defined as communicative behavioral process of informally exchanging positive or negative information between consumers through direct and indirect experiences of individuals [17].

Ryu, K. et. al. (2012) defined the recommendation intention as the process of informally recommending positive information about personal direct experience or indirect experience to others. They also stated that it is a personal evaluation and deliverance to others of the positive things they felt after consumers consumed [18].

The reasons that positive word-of-mouth is important among the customer's reactions are followings: First, positive word-of-mouth is related to one-on-one exchanges and has a great effect compared to other exchanges. 
Secondly, because word of mouth is not created by companies but it has a source or consumers, it is understood as a more reliable source of information. Lastly, a behavior of complaining is done only to sellers, and relevant word-of-mouth has a characteristic of spreading rapidly to many people around them. Therefore, the main determinants of word-of-mouth behavior are satisfaction and dissatisfaction felt by customers [19], [20].

\section{RESEARCH DESIGN}

\subsection{RESEARCH OBJECT AND RESEARCH MODEL}

In order to carry out this study, a survey was conducted on residents of high-rise residential complex located in a metropolitan area in China. The questionnaire of survey consists of three parts: management service quality, residential satisfaction, and the intention of recommendation. The questionnaire questions about variables except demographic characteristics were composed of Likert 5-point interval scale. In this study, a research model was set up as shown in Figure 2 to examine the impacts of management service quality as an independent variable on satisfaction and behavioral intention based on literature research and precedents [21].

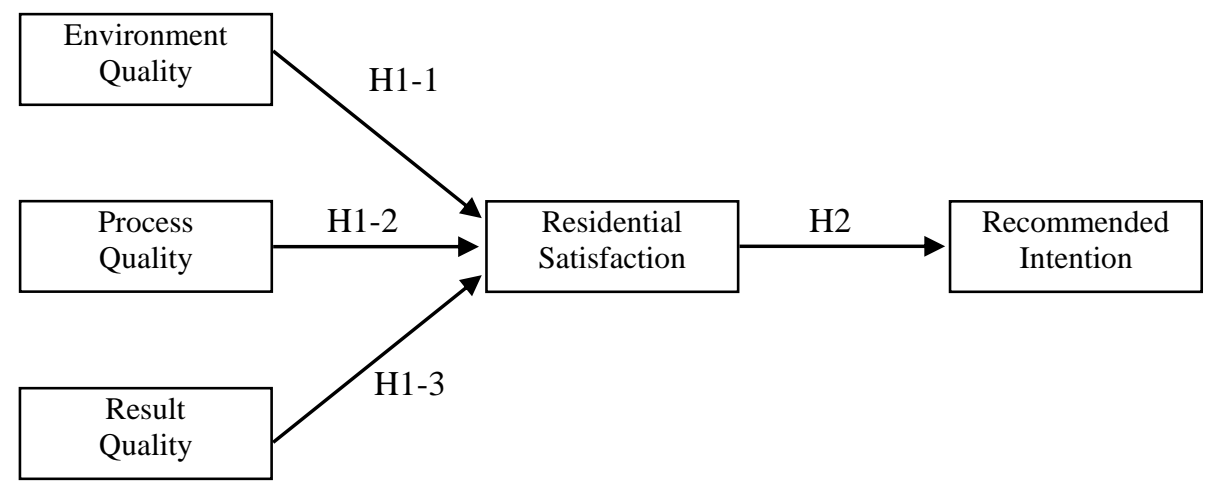

Fig. 2 Research Model

\subsection{RESEARCH HYPOTHESIS}

This study sets up the following hypotheses based on a precedent that the management service quality of high-rise apartments has an effect on residents' satisfaction and intention of recommendation.

Hypothesis 1: The quality of management service will have a positive effect on the satisfaction of residents.

1-1 Environmental quality will have a positive effect on residents' satisfaction.

1-2 Process quality will have a positive effect on residents' satisfaction.

1-3 Result quality will have a positive effect on residents' satisfaction.

Hypothesis 2: Satisfaction on the part of residents living in high-rise apartment will have a positive effect on the intention of recommendation.

\section{EMPIRICAL ANALYSIS}

\subsection{DATA COLLECTION, MEASUREMENT AND ANALYTICAL METHOD}

The survey for the empirical analysis of this study was conducted for about three months from December 2019 to February 2020 for those who have lived in high-rise apartments in China. 265 copies of questionnaire were collected through the online questionnaire method, and 240 copies were finally used for analysis, excluding 25 copies that were insincere.

The measurement of variables was made by a five-point scale on environmental quality (6 items), process quality (6 items), result quality (5 items), resident satisfaction (7 items), and recommendation intention (4 items) based on the existing precedent studies related to the management service quality of high-rise apartments. And SPSS 25.0 was used for statistical process for the analysis on data surveyed. Frequency analysis was conducted to identify the general characteristics of the subjects, and reliability analysis and factor analysis were conducted 
to verify the reliability and validity of the measurement tools used in the empirical study. Multiple regression analysis was also utilized to examine the research hypotheses.

\subsection{STATUS OF DATA}

When result characteristics are viewed after analyzing the general status of the data, $48.3 \%$ of the male (116 persons) and $51.7 \%$ (124 persons) of the female were shown in the data.

Table 3. Data Characteristics

\begin{tabular}{|c|c|c|c|c|c|c|c|}
\hline \multicolumn{2}{|c|}{ Demographic Profile } & \multirow{2}{*}{$\begin{array}{r}\text { Frequency } \\
116\end{array}$} & \multirow{2}{*}{ Ratio } & \multicolumn{2}{|c|}{ Demographic Profile } & \multirow{2}{*}{$\begin{array}{r}\text { Frequency } \\
10\end{array}$} & \multirow{2}{*}{$\begin{array}{ll}\text { Ratio } \\
\end{array}$} \\
\hline & male & & & \multirow{4}{*}{ Age } & $20 \mathrm{~s}$ & & \\
\hline Gता & female & 124 & 5 & & $30 \mathrm{~s}$ & 31 & 12.9 \\
\hline \multirow{4}{*}{ Provin } & Shandong/Shan & 117 & 4 & & $40 \mathrm{~s}$ & 143 & 59.6 \\
\hline & Beijing/Tianjin & 72 & 30 & & over $50 \mathrm{~s}$ & 56 & 23.3 \\
\hline & $\begin{array}{c}\text { Guangzhou/Heb } \\
\text { Henan }\end{array}$ & 32 & 1. & \multirow{8}{*}{ Occupat } & student & 32 & 13.3 \\
\hline & Others & 19 & 7 & & $\begin{array}{c}\text { office worker or } \\
\text { official }\end{array}$ & 69 & 28.8 \\
\hline \multirow{7}{*}{$\begin{array}{r}\text { Acaden } \\
\text { backgro }\end{array}$} & below high school gr & 18 & 7 & & $\begin{array}{c}\text { small business or } \\
\text { owned }\end{array}$ & 38 & 15.8 \\
\hline & college graduat & 20 & 8 & & $\begin{array}{c}\text { professional } \\
\text { technical }\end{array}$ & 5 & 2.1 \\
\hline & \multirow{2}{*}{ 4-year college grad } & \multirow{2}{*}{73} & \multirow{2}{*}{31} & & managemen & 21 & 8.8 \\
\hline & & & & & housewife & 3 & 1.3 \\
\hline & graduate degre & 61 & $2:$ & & \multirow{2}{*}{ others } & \multirow{2}{*}{72} & \multirow{2}{*}{30.0} \\
\hline & doctorate & 52 & 2 & & & & \\
\hline & others & 16 & 6 & \multirow{6}{*}{$\begin{array}{r}\text { Average } \mathrm{m} \\
\text { incom } \\
(\mathrm{CNY}\end{array}$} & less than 2 mill & 171 & 71.3 \\
\hline \multirow{5}{*}{ Period of re: } & less than 1 yeal & 51 & 2 & & $2 \sim 3$ millior & 31 & 12.9 \\
\hline & 1 less than 3 yed & 73 & 30 & & $3 \sim 4$ millior & 11 & 4.6 \\
\hline & 3 less than 5 yes & 52 & 2 & & $4 \sim 5$ millior & 3 & 1.3 \\
\hline & 5 less than 7 yed & 25 & 10 & & $5 \sim 6$ millior & 6 & 2.5 \\
\hline & over 7 years & 39 & 10 & & over 6 millio & 18 & 7.5 \\
\hline & Total responses & 240 & 10 & & otal responses & 240 & 100.0 \\
\hline
\end{tabular}

The age of '40s' was the most with $59.6 \%$ (143 people), 'Shandung/Shanxi province' with $48.8 \%$ (117 persons), '4-year college graduation' with $30.4 \%$ (73 persons), and 'office worker/public servant' with $28.8 \%$ (69 persons). Besides, residents of ' 1 year to less than 3 years' were the most with $30.4 \%$ ( 73 persons) and the average monthly household income with 'less than 2 million CNY' was shown the most with $71.3 \%(171$ persons).

\subsection{RELIABILITY AND VALIDITY}

This study used Cronbach's $\alpha$ coefficient showing the internal consistency of the data in order to analyze the reliability of the measurement tool. In addition, factor analysis was conducted to verify the validity of the measurement items. The factor analysis was performed by using the Varimax-rotation method by the principal component analysis, and only the factors with the eigen value of 1.0 or more were analyzed. As shown in Table 4 , Cronbach' $\alpha$ value is shown to be more than 0.9 for each factor, so it is analyzed to be reliable. In addition, the factor analysis results showed that five factors were derived, and the total variance of the whole factor was $83.704 \%$. 
Table 4. Result of Reliability and Validity Analysis

\begin{tabular}{|c|c|c|c|c|c|}
\hline Variables & Measurement items & Factor Loading & Cronbach' & Eigen Value & $\%$ of Varia \\
\hline $\begin{array}{l}\text { Environment } \\
\text { quality }\end{array}$ & $\begin{array}{l}\text { - degree of noise and hygiene } \\
\text { - cleanliness of internal environment } \\
\text { - level of outer landscaping } \\
\text { - harmony with roundabouts } \\
\text { - convenience of amenities facility } \\
\text { - convenience and safety of parking lot }\end{array}$ & $\begin{array}{l}.884 \\
.855 \\
.827 \\
.811 \\
.787 \\
.710\end{array}$ & .950 & 3.032 & 10.828 \\
\hline $\begin{array}{l}\text { Process } \\
\text { quality }\end{array}$ & $\begin{array}{l}\text { - degree of management staff's interest on } \\
\text { residents' requirements } \\
\text { - management staff's attitude and manner } \\
\text { - level of management staff's expertise } \\
\text { - availability of access and contact to } \\
\text { management staff } \\
\text { - expeditiousness of solving managerial } \\
\text { problems } \\
\text { - expeditiousness of management staff cor } \\
\text { with residents' requirements }\end{array}$ & $\begin{array}{l}.760 \\
.755 \\
.748 \\
.738 \\
.720 \\
.713 \\
7\end{array}$ & .954 & 1.387 & 4.955 \\
\hline $\begin{array}{l}\text { Result } \\
\text { quality }\end{array}$ & $\begin{array}{l}\text { - improvement of benefit in family life } \\
\text { - contribution to family's profit } \\
\text { - improvement of comfort in family life } \\
\text { - promotion of benefit in outside/unit facil } \\
\text { - reduction of work on oneself and his or } \\
\text { household }\end{array}$ & $\begin{array}{l}.875 \\
.856 \\
.855 \\
.834 \\
.823\end{array}$ & .967 & 2.077 & 7.417 \\
\hline $\begin{array}{l}\text { Residential } \\
\text { satisfaction }\end{array}$ & $\begin{array}{l}\text { - satisfaction on outer landscaping } \\
\text { - satisfaction with cleanliness and hygiene } \\
\text { complex } \\
\text { - satisfaction with facility maintenance of } \\
\text { of the apartment } \\
\text { - satisfaction with outer shape and colorin } \\
\text { - satisfaction with nearby amenities and re } \\
\text { space } \\
\text { - satisfaction with location, transportation } \\
\text { roundabouts } \\
\text { - satisfaction with parking space and its } \\
\text { maintenance }\end{array}$ & $\begin{array}{l}.791 \\
.767 \\
.762 \\
.744 \\
.732 \\
.731 \\
.686\end{array}$ & .957 & 15.731 & 56.183 \\
\hline $\begin{array}{l}\text { Recommended } \\
\text { intention }\end{array}$ & $\begin{array}{l}\text { - recommendation intention on apartment } \\
\text { occupancy } \\
\text { - positive verbal transference on the reside } \\
\text { conditions of apartment } \\
\text { - intention of recommendation of purchase } \\
\text { apartment } \\
\text { - continuous residential intention }\end{array}$ & $\begin{array}{l}.860 \\
.856 \\
.824 \\
.791\end{array}$ & .962 & 1.210 & 4.322 \\
\hline \multicolumn{6}{|c|}{$\begin{array}{l}\text { Kaiser-Meyer-Olkin, Statistical measure }=.911 \text {, } \\
\text { Bartlett's test of sphericity approximation } \gamma^{2}=8.872 .447(\text { d.f. }=378, p=.000)\end{array}$} \\
\hline
\end{tabular}

\subsection{CORRELATION ANALYSIS}

As shown in Table 5, the results of correlation analysis of this study showed that most of the items were significant, and suitability of the data is secured as the correlation coefficient.

Table 5. Result of Correlation Analysis

\begin{tabular}{|r|rrr|r|r|r|r|r|}
\hline Variables & Mea & S.D & (1) & (2) & (3) & (4) & (5) \\
\hline \hline (1) Environment quality & 3.76 & .95 & 1 & & & & \\
\hline
\end{tabular}




\begin{tabular}{|l|rr|r|r|r|r|r|}
\hline (2) Process quality & 3.80 & .85 & $.693 *$ & 1 & & & \\
\hline (3) Result quality & 3.85 & .91 & $.445 *$ & $.603 *$ & 1 & & \\
\hline (4) Residential satisfactior & 3.72 & .80 & $.588 *$ & $.686 *$ & $.614 *$ & 1 & \\
\hline (5) Recommended intentic & 3.90 & .90 & $.384 *$ & $.557 *$ & $.538 *$ & $.687 *$ & 1 \\
\hline
\end{tabular}

$* * * \mathrm{p}<.01$

\subsection{HYPOTHESIS VERIFICATION}

4.5.1 RESULT OF VERIFICATION ON HYPOTHESIS 1: In this study, regression analysis is made to identify the relationship between management service quality, satisfaction and recommendation intention of high-rise residential complex apartments in China. The results are as follows. First, the verification result of Hypothesis 1 that the quality of management of high-rise apartments will have a positive (+) effect on the satisfaction of residents is as shown in Table 6.

Table 6. Result of Hypothesis Test 1 (Multiple Regression Analysis)

\begin{tabular}{|c|c|c|c|c|c|c|c|}
\hline Distinction & Sum of $S$ & $d . f$. & Mean Squa & $\mathbf{F}$ & Sig & $\mathbf{R}$ & $\mathbf{R}^{2}$ \\
\hline Regression & 85.5 & 3 & 28.511 & 98.0 & .000 & & \\
\hline Residual & 68.6 & 236 & 0.291 & & & .74 & .55 \\
\hline Total & 154.1 & 239 & & & & & \\
\hline \multirow[t]{2}{*}{ Model } & \multicolumn{2}{|c|}{$\begin{array}{c}\text { Nonstandardizat } \\
\text { Coefficient }\end{array}$} & \multirow{2}{*}{$\begin{array}{c}\text { Standardizat } \\
\text { Coefficien } \\
\text { (Beta) }\end{array}$} & \multirow[t]{2}{*}{$\boldsymbol{t}$} & \multirow[t]{2}{*}{ Sig } & \multicolumn{2}{|c|}{ collinearity stati } \\
\hline & $\mathbf{B}$ & S. E & & & & Tolera & VII \\
\hline (Constant) & .75 & .177 & & 4.2 & .00 & & \\
\hline Environment qua & .168 & .05 & .200 & 3.3 & .001 & .518 & 1.93 \\
\hline Process qualit & .342 & .06 & .363 & 5.3 & .000 & .41 & 2.43 \\
\hline Result quality & .26 & .048 & .306 & 5.6 & .000 & .63 & 1.57 \\
\hline
\end{tabular}

Dependent variables: residential satisfaction

$* \mathrm{p}<.1, * * \mathrm{p}<.05, * * * \mathrm{p}<.01$

As a result of multiple regression analysis, the explanatory power $\left(\mathrm{R}^{2}\right)$ of the regression formula is .555 , and the result of variance analysis for statistical significance verification of the regression coefficient shows that the significance probability value is .0000 , which is meaningful with the value of the significance level .01. The result of multiple regression analysis shows that environmental quality, process quality and result quality under the management service quality of high-rise apartments have a statistically significant positive effect on residents' satisfaction, so all hypotheses 1-1, 1-2, and 1-3 are adopted.

4.5.2 RESULT OF VERIFICATION ON HYPOTHESIS 2: The result of verifying Hypothesis 2 that the residents' satisfaction in the research model will have a positive $(+)$ effect on the recommendation intention are as follows in Table 7.

As a result of analysis, the explanatory power $\left(\mathrm{R}^{2}\right)$ of the regression formula was .472 , and the analysis of variance shows that the significance probability value is .0000 , which is relevant at the significance level .01. As a result of simple regression analysis, the residential satisfaction with high-rise apartments had a statistically significant positive effect on the intention of recommendation, and the hypothesis 2 is supported.

Table 7. Result of Hypothesis Test 2 (Simple Regression Analysis)

\begin{tabular}{|rrr|rr|r|r|r|}
\hline Distinctio & Sum of Sq & d.f. & Mean Squ & F & Sig. & R & $\mathbf{R}^{2}$ \\
\hline \hline Regressio & 91.958 & 1 & 91.958 & 212.5 & $.000 *$ & & \\
Residual & 102.99 & 238 & 0.433 & & & .68 & .47 \\
\hline
\end{tabular}




\begin{tabular}{|c|c|c|c|c|c|}
\hline Total & $194.94 \oint$ & 239 & & & \\
\hline \multirow[t]{2}{*}{ Model } & \multicolumn{2}{|c|}{$\begin{array}{c}\text { Nonstandardizatio } \\
\text { Coefficient }\end{array}$} & \multirow{2}{*}{$\begin{array}{c}\text { Standardization Coeff } \\
\text { (Beta) }\end{array}$} & \multirow[t]{2}{*}{$t$} & \multirow{2}{*}{ Sig. } \\
\hline & B & S. E. & & & \\
\hline (Constant & 1.023 & .202 & & 5.06 & .000 \\
\hline $\begin{array}{l}\text { Residenti: } \\
\text { Satisfactic }\end{array}$ & .772 & .053 & .687 & 14.57 & $.000 * * *$ \\
\hline
\end{tabular}

Dependent variable: recommended intention

$* \mathrm{p}<.1, * * \mathrm{p}<.05, * * * \mathrm{p}<.01$

\section{CONCLUSION}

This study is to empirically examine how the quality of management service - environmental quality, process quality and result quality - perceived by the residents of high-rise residential complex of China affects the satisfaction of the residents and how the satisfaction of the residents affects the recommendation intention. The results and implications are as follows.

As a result of the empirical analysis, environmental quality, process quality and result quality as sub-factors of management service quality of high-rise apartments in China have a significant effect on the satisfaction of occupancy. Furthermore, it is thought that the occupancy satisfaction has a significant effect on the recommendation intention. Also, it is shown that the process quality (standardization coefficient $\beta=.363$, $t=5.362)$, result quality $(\beta=.306, t=5.610)$, and environmental quality $(\beta=.200, t=3.319)$ among the sub-service quality factors had a great influence in their order.

Such results of analysis are similar to those in the existing research on service quality, and it is the result showing that the process of offering service has a great impact on residential satisfaction. Therefore, in order to improve the satisfaction of the residents of high-rise apartments and to derive positive attitudes and follow-up behaviors, it can be said that it is important to give priority to paying attention to residents' requirements and taking a quick and friendly treatment of them rather than focusing on making efforts to improve the physical environment quality and its resulting increase of quality.

However, this study has limitations of its scope and samples because it confined its survey into limited period and some specific areas in China. Therefore, it seems to be necessary to expand the scope of the survey in order to overcome these limitations and to continue to study the various conditions of the residence, such as the development of measurement items proactively reflecting the characteristics of the residence in high-rise apartments.

\section{REFERENCES}

[1] Park, Hyo-Gyun. "A Study on the Expressional Characteristics in the Contemporary Architecture on Skyscraper." Kyung-Won University Master Thesis (2008): 7-12.

[2] Arijit Maity, "Critical Factors Responsible for Failure of Construction Project in Kolkata: an Empirical Study", International Journal of Metallurgical \& Materials Science and Engineering (IJMMSE), Vol. 7, Issue 4, pp, 13-30

[3] Cha, Yong-Sub, "A Study on the Affecting of Apartments Management Service Quality on Residential satisfaction Level and Intention of Recommendation: Focused on Metropolitan Apartments." Seoul Venture University Doctoral Dissertation (2014): 33-62.

[4] Gokul K Bayan, "Bi-Layer Footing Foundation System for Multistorey Building-towards a New Conception and Practices", International Journal of Civil, Structural, Environmental and Infrastructure Engineering Research and Development (IJCSEIERD), Vol. 3, Issue 3,pp , 59-78

[5] Chen Anna. "A Study on the Form and Appearance of Chinese High-rise Buildings." Yeung-Nam University Master Thesis (2015): 6-10.

[6] Alabi Paul \& Ebiwari Wokekoro, "Prospects for Professional Management of Multi-Tenanted Commercial Properties in Port Harcourt (PHALGA), Nigeria", International Journal of Business and General Management (IJBGM), Vol. 7, Issue 5, pp; 41-54

[7] CTBUH. The Status of Newly Built Tall Buildings in 2018, 2018. 
[8] Elenwo, E \& Akujuru, V.A, "The Expert Valuers Views on the Critical Variables Influencing Residential Property Values in Port Harcourt Metropolis", International Journal of Humanities and Social Sciences (IJHSS), Vol. 7, Issue 4, pp; 193-204

[9] Grönroos, C. “A Service Quality Model and Its Marketing Implications.” European Journal of Marketing 18 (1984): 6-44.

[10] Pushpanjali Arya, Jagdish Chandra \& Akanksha Arya, "Urbanisation, Problems of Migration and Environmental Challenges in Uttarakhand”, IMPACT: International Journal of Research in Humanities, Arts and Literature (IMPACT: IJRHAL), Vol. 8, Issue 7, pp, 35-42

[11] Parasuraman A., V. A. Zeithaml and L. Berry. "A Conceptual Model of Service Quality and Its Implications for Future Research.” Journal of Marketing 49(Fall) (1985): 41-50.

[12] Mehnaz Tabassum \& Shirajom Monira Khondker, "Study of Ecological Impact of Vegetation in Urban Residential Plot and its Impact on Outdoor Environment", International Journal of Civil Engineering (IJCE), Vol. 2, Issue 3, pp, 109-122

[13] Chae-Kwan Lim and Kyeng-Bong. "The Effect of Service Quality of Legal Services on Customer Satisfaction." International Journal of Smart Business and Technology. 5(2) (2017). GVPress. pp:7-14. http://dx.doi.org/10.21742/IJSBT.2017.5.2.02

[14] Rust, R. T. and R. L. Oliver. "Service Quality: Insights and Managerial Implications from the Frontier, in Service Quality: New Directions in Theory and Practice." Ronald T. Rust and Richard L. Oliver, eds., Thousand Oaks, CA: Sage Publications (1994): 1-19.

[15] Bitner, M. J. and A. R. Hubert. "Encounter Satisfaction versus Overall Satisfaction versus Quality, in Service Quality: New Directions in Theory and Practice.” Ronald T. Rust and Richard L. Oliver, eds., Thousand Oaks, CA: Sage Publications (1994): 72-94.

[16] Choi, Gwang-Lyong. "A Study on the Influence of Managing Service Quality and Service Value in SuperHigh-Rise Residential Apartment on the Satisfaction and the Recommendation." Ho-Seo University Doctoral Dissertation (2012): 59-65.

[17] Oliver, R. L. "Measurement and Evaluation of Satisfaction Process in Retail Setting.” Journal of Retailing 57 (1981): 25-48.

[18] Engel, J. F., Blackwel, R. D., and Kolat, D. T. Consumer Behavior (4th ed.) NY: The Dryden Pres, 1982.

[19] Anderson, R. E. and Weitz, B. "The Use of Pledges to Build and Sustain Commitment in Distribution Channels." Journal of Marketing Research 29 (1992): 18-34.

[20] Ha, Kyu-Soo and Jin, Seon-Jin. "A Study on the Housing Satisfaction According to the Variables of Apartment Dwellers.” Family and Environment Research 48(1), (2010): 83-96.

[21] Burby, Raymond J. and William M. Rohe. "Deconcentration of Public Housing: Effects on Residents' Satisfaction with Their Living Environments and Their Fear of Crime." Urban Affairs Quarterly 25.1 (1989): 117-141.

[22] Shin, Yong-Sun and Kim, Moon-Seop. "The Influence of Service Recovery Justice on Intention to Recommend for Retailer.” Journal of Distribution Science 18.2 (2020): 91-98.

[23] Roy, S. K., M. Lassar, W. and T. Butaney, G. "The Mediating Impact of Stickiness and Loyalty on Word-ofMouth Promotion of Retail Websites: A Consumer Perspective.” European Journal of Marketing 48.9/10 (2014): 1828-1849.

[24] Ryu, K., Lee, H.R. and Gon Kim, W. "The Influence of The Quality of the Physical Environment, Food, and Service on Restaurant Image, Customer Perceived Value, Customer Satisfaction, and Behavioral Intentions." International Journal of Contemporary Hospitality Management 24.2 (2012): 200-223.

[25] Kim, Tae-Yeon. "The effect of Service Quality of Sharing Economy on Guest Satisfaction, Revisit and Recommendation intention.” Han-Yang University Master Thesis (2017): 35-48.

[26] Tripathi, G. "Customer Satisfaction and Word of Mouth Intentions: Testing the Mediating Effect of Customer Loyalty.” Journal of Services Research 17.2. (2017): 1-17.

[27] Feng Jing, Chae-Kwan Lim. "An Empirical Study on the Effect of Management Service Quality of High-rise Apartment on Residential Satisfaction: Focused on High-rise Apartment in China." International Journal of 
IT-based Management for Smart Business, 7(1) (2020), Global Vision Press, pp: 23-30/1742/IJITMSB. 2020.7.1.04

[28] Ji-Hee Jung and Jae-Ik Shin. "The Effects of e-Service Quality on Intention of Continuous Use and Recommendation Intention in Internet Primary Bank." International Journal of IT-based Management for Smart Business. 4(2) 2017. GVPress. pp:7-12.http://dx.doi.org/10.21742/IJITMSB.2017.4.2.02

[29] Kang, Seohee, Choi, Hwayeol. "The Effect on Intention to Recommendation and Satisfaction of Communication Type of Service Provider: Based on Food-Service Industry." International Journal of Smart Business and Technology. 6(1) 2018. GVPress. pp:39-46.http://dx.doi.org/10.21742/ IJSBT.2018.6.1.05 